\title{
Mental and Physical Well-being of People Working in Helping Professions, Employed in
} Youth Educational Centres and Sociotherapy Centres

\section{Mental and Physical Well-being of People Working in Helping Professions}

Justyna Szrajda ${ }^{1}$, Ewa Sygit - Kowalkowska ${ }^{2}$, Magdalena Weber-Rajek ${ }^{3}$, Marcin Ziółkowski, Alina Borkowska ${ }^{5}$

1. Department of Hygiene, Epidemiology and Ergonomics, Collegium Medicum in Bydgoszcz, Nicolaus Copernicus University in Toruń,ul. Curie-Sklodowskiej 9, 85-094 Bydgoszcz

2. Institute of Psychology, Department of Organizational and Management Psychology, Kazimierz Wielki University in Bydgoszcz, ul. Staffa 1, 85-867 Bydgoszcz, Poland

Corresponding Author: ewasygit@gmail.com

3. Department of Physiotherapy, Division of Clinical Physiotherapy, Collegium Medicum in Bydgoszcz, Nicolaus Copernicus University in Toruń, ul. Technikow 3, 85-801 Bydgoszcz, Poland

4. Department of Preventive Nursing, Division of Psychiatric Nursing, Collegium Medicum in Bydgoszcz, Nicolaus Copernicus University in Toruń, ul. Lukasiewicza 1, 85-821 Bydgoszcz, Poland

5. Department of Clinical Neuropsychology, Ludwik Rydygier Collegium Medicum in Bydgoszcz, Nicolaus Copernicus University in Toruń, ul. M. Curie Skłodowskiej 9, 85-094 Bydgoszcz, Poland 
27 ewasygit@gmail.com (ESK)

* Corresponding author

\section{These authors contributed equally to this work.}

JSZ and ESK are Joint Senior Authors

\section{These authors also contributed equally to this work}

MWR and $\mathrm{MZ}$ and $\mathrm{AB}$

(1)




\section{Abstract}

Representatives of helping professions are particularly exposed to occupational stress. The aim of the study was to evaluate mental and physical well-being, as well as their correlates and predictors in a group of employees working at youth educational centres and sociotherapy centres. A total of 96 employees working at youth educational centres and sociotherapy centres in Kujawsko-Pomorskie voivodeship took part in the study. The following psychometric tools were used: the Psychosocial Working Conditions Questionnaire, the Mini-COPE, the LOT-R, and the GSES. The results obtained indicate that people working in helping professions experience mental and physical health problems. Only $3 \%$ of the subjects declared they sleep all night. Over $40 \%$ and over $35 \%$ of the subjects estimate they suffer from low mood and irritation episodes, respectively, rather frequently or continually. Subjects with poorer mental health are more likely to use Helplessness, Avoidance behaviours, or Turning to religion to cope with stress. The strongest predictor of mental wellbeing is the sense of self-efficacy. Whereas, the strongest predictor of physical well-being is the ability to cope with stress by giving into the feeling of Helplessness. The study demonstrated poor mental and physical well-being of the subjects. A statistically significant correlation was found between sex and the level of mental and physical health. Employees working at youth educational centres and sociotherapy centres with better mental and physical well-being had a stronger sense of self-efficacy and a higher level of life optimism. Hence, the sense of self-efficacy is a predictor for better mental well-being.

\section{Introduction}

Work conditions are defined as all the factors present in the work environment related to performing work, which affect employees' health and, if negative, may generate occupational stress [1,2]. If not eliminated, prolonged occupational stress has a negative impact on 
employee's health, deteriorates physical condition, and may cause serious emotional burden $[3,4,5]$. In the published reports, the occupational group of teachers is described as one of the groups particularly susceptible to stress factors in their work environment $[6,7]$.

When it comes to employees working at youth educational centres and sociotherapy centres, they are exposed to particular work conditions. The aim of youth educational centres is to eliminate the causes and symptoms of social maladjustment of the youth and prepare them to comply with current social and legal standards. Youth sociotherapy centres are designated for children and youth who due to developmental and social functioning disorders, and learning difficulties require their education and work, as well as sociotherapy methods used, to be individually-adjusted. The most common causes for placing young people in such institutions include: evading compulsory education, signs of demoralisation (use of alcohol, intoxicating substances, and prostitution), aggressive and violent behaviours towards their peers and environment, suicide attempts, running away from home, personality disorders, belonging to an organised criminal group, or committing criminal offences (robbery, vandalism, theft, battery). Therefore, it can be assumed that in addition to the traditional stressors for teachers, the staff in such centres is burdened with additional qualification requirements which are difficult to meet.

Teachers and educators working at such centres belong to helping professions, and are required to work for the well-being of others, show commitment, and establish emotional contact. Occupational load may contribute to mental health problems in people working in helping professions. Due to the particular nature of youth-teacher interactions the staff is exposed to occupational stress. At the same time, the teachers' educational success depends on their ability to cope with stress $[8,9]$.

To a substantial extent, the ability to cope with stress factors depends on psychological resources. Personal traits that have a positive effect on health include: self-acceptance, sense 
of authorship, sense of control, sense of self-efficacy, ability to effectively solve tasks and influence one's environment, intelligence and flexibility, thoughtfulness and emotional competences, as well as optimism in life $[10,11,12]$.

\section{The Aim of the Study}

The aim of the study was to evaluate mental and physical well-being (interchangeably referred to as 'mental health' and 'physical health' in this paper), as well as their correlates and predictors in a group of employees working at youth educational centres and sociotherapy centres.

The following study questions were asked:

1. What is the level of mental and physical well-being of the subjects?

2. What is the correlation between the level of the mental and physical well-being, age, job tenure, and sex in the studied group?

3. What is the correlation between the level of mental and physical well-being and personal resources, such as sense of self-efficacy, optimism in life, and strategies for coping with stress in the studied group?

4. Which of the studied personal resources is a predictor for mental and physical wellbeing in the studied group?

The study was based on scientific reports, therefore we assumed that women will show a lower level of well-being than men, and that dealing with stress, optimism and self-efficacy would be predictors of better health at work. Avoiding behaviours aimed at dealing with stress were a predictor of bad mood $[13,14]$.

\section{Materials and Methods}

The research was approved by the Bioethics Committee of Nicolaus Copernicus University, functioning at Collegium Medicum in Bydgoszcz (KB 628/2016). The study subjects were 
teachers and educators from five youth educational centres and sociotherapy centres in Kujawsko-Pomorskie voivodeship. 96 subjects ( 72 women and 24 men), aged 26 to 55 years old (mean age was 42 years $\underline{+} \mathrm{SD}=9$ ), and with a job tenure of 1 to 30 years (average job tenure was 11 years; $\underset{+}{\mathrm{SD}}=6$ ) were enrolled into the study.

The following tools were used in the study:

1. The Psychosocial Working Conditions questionnaire (Polish: "Psychospołeczne warunki pracy") developed by R. Cieślak and M. Widerszal-Bazyl [15]. The theoretical D scale and two empirical scales (D1 and D2) examining mental and physical well-being were used in the study. The question "What is the level of your well-being?" was the main component of the theoretical scale. The D1 scale included an overall assessment of physical health and stress level, as well as somatic symptoms, such as headache, stomach ailments, and heart problems. The mental well-being factor focused on the evaluation of negative emotional states, life and job satisfaction, and self-confidence. Cronbach's $\alpha$ for the D scale was .94 (.86 for the D1 scale and .83 for the D2).

The presentation of the results includes qualitative analyses of the questions, which are acceptable methods for analysing questionnaire results. The collected quantitative and qualitative data were compared with the results for teachers, such as standard ten scores and response frequencies, included in the tool manual.

2. The Mini-COPE (Coping Inventory) is used to measure stress coping abilities. It was developed by Charles S. Carver, and adapted in Poland by Z. Juczyński and N. Ogińska-Bulik [16]. The tool is used to evaluate strategies applied to cope with stress. A subject responds to each statement using a scale from 0 to 3 , where 0 means "I almost never do it" and 3 means "I almost always do it". The higher the result, the more intense is the use of a selected strategy. The factor score structure employs the 
following strategies: Active coping, Helplessness, Avoidance behaviours, Searching for support, Turning to religion, Acceptance, and Sense of humour. Cronbach's $\alpha$ for the Mini-COPE scale ranged from .79 to .87 .

3. The LOT-R (Life Orientation Test) developed by M. F. Scheier, Ch. S. Carver, and M. W. Bridges, and adapted in Poland by R. Poprawa and Z. Juczyński [16]. This test is used to evaluate dispositional optimism understood as a personality trait. Optimism, understood this way, is a generalized positive expectancy for good outcomes. Using a five-grade scale, subjects estimate to what extent a given statement applies to them.

Statistical analyses were conducted using the IBMSPSS Statistics 21 package.

The Kolmogorov-Smirnov test was used to determine the normality of data distribution.

A correlation between variables was evaluated using the Spearman's rho and Pearson's $r$ coefficients. Linear regression analysis with the stepwise method was also used. We assumed a confidence level of $p<0.05$.

170 Firstly, the data was analysed using basic descriptive statistics, and the Kolmogorov-Smirnov 
skewness value for these variables exceeds the contractual absolute value of 0.8 only in the case of seniority, and consequently the distribution of other scales is not grossly asymmetrical with respect to the Gauss curve. It was therefore decided that parametric tests will be carried out with the participation of other variables.

\section{Results}

The sten scale was used to describe the level of mental and physical well-being of the respondents. The mental well-being results were nearly evenly distributed between three categories. 31 subjects demonstrated poor mental health, whereas 29 and 36 subjects showed average and high mental health, respectively. As far as physical well-being was concerned, $33.3 \%$ of the respondents rated it as low, $37.5 \%$ as high, and $29.2 \%$ as average.

According to the procedure described in the "Proposal for analysis of questionnaire results" chapter in the "Psychosocial work conditions" manual, a percentage of the responses to several questions was used in the analysis. The responses were then compared to the percentage distribution of teachers' responses in the questionnaire manual (Tab. I, Tab. II).

Table. I. This is the Table I. Qualitative analyses of subjects' responses versus standards for teachers (D2 scale; mental well-being).

The analyses showed that over $40 \%$ and over $35 \%$ of the subjects estimate they suffer from low mood and irritation episodes, respectively, continually or frequently (Tab. I). When it comes to sense of nervousness, over $30 \%$ of the subjects estimate they "continually" or "rather frequently" experience this state. 40 subjects declared "rather frequent", and 8 subjects "continual" problems concentrating (which is about $11.52 \%$ of the subjects versus $4.8 \%$ of the norm). More than six times as many respondents declared they experienced loneliness "rather frequently" compared with teachers" answers presented in the questionnaire manual. 
Tab. II. This is the Table II. Qualitative analyses of subjects' responses versus standards

The largest differences between the subjects' results and the standards for teachers were observed with regard to sleep self-evaluation (Tab. II). Nearly half of the subjects selected the answer "I do not sleep at all", which is more than six times as many respondents compared that they sleep all night - and this result is over sixteen times lower than the official standard.

Qualitative analysis also demonstrated that more than five times as many employees working at the centres assessed their health as very bad and quite bad in comparison to the reference group of teachers in the questionnaire manual $(38.53 \%$ of the sample vs. $6.9 \%$ of the teachers). The study participants experienced constant headaches and very frequent tightness and/or pain in the chest more than nine times as often as the reference group of teachers in the questionnaire manual. Nearly $35 \%$ of the respondents reported feeling weak "frequently" or "very frequently" (compared to less than $12 \%$ of the standard quoted in the manual). concentrating more than nine times as often as the group of teachers.

Using random samples, a correlation between the level of the mental and physical well-being, age, job tenure, sex, place of work, and job position were evaluated with the Spearman's rho test and Student's t-test. Correlations between age, job tenure, and the level of mental well-being proved to be statistically insignificant $(p=0.547 ; p=0.562)$. When it comes to the sex variable, the obtained result proved to be statistically significant $-t(94)=$ $-2.78 ; p<0.01 ; 95 \% C l[-0.73 ;-0.12] ; d=0.664$. As the means indicate, women $(M=3.34$ $S D=0.67)$ scored lower in mental well-being than men $(M=3.86 ; S D=0.50)$. 
The relationship between age, job tenure, and physical well-being also turned out to be statistically insignificant $(\mathrm{p}=0.148 ; \mathrm{p}=0.886)$. The data obtained using independent samples and the Student's t-test were statistically significant with respect to the gender variable $\mathrm{t}(62.71)=-3.79 ; \mathrm{p}<0.001 ; 95 \% \mathrm{Cl}[-0.78 ;-0.24] ; \mathrm{d}=0.811$. This means that the level of physical well-being in women $(n=73)$ is different than that of men $(n=23)$. As indicated by the mean scores, women $(\mathrm{M}=3.59 ; \mathrm{SD}=0.79)$ scored lower on this scale than men $(\mathrm{M}=4.10 ; \mathrm{SD}=0.48)$

During the next part of the study we analysed the correlation between the level of mental well-being, physical well-being, sense of self-efficacy, optimism in life, and strategies for coping with stress using the Pearson $r$ method. The results showed that the level of mental well-being is statistically significantly correlated with strategies for coping with stress, such as Helplessness $(\mathrm{r}=-0.289 ; \mathrm{p}=0.004)$, Avoidance behaviours $(\mathrm{r}=-0.256 ; \mathrm{p}=0.012)$, and Turning to religion $(r=-0.224 ; p=0.028)$. These relationships are negative and weak, which means that subjects with poorer mental well-being are more likely to cope with stress by giving into Helplessness, Avoidance behaviours, or Turning to religion. Furthermore, mental well-being is statistically significantly correlated with the sense of self-efficacy $(r=0.401$; $\mathrm{p}=0.001)$ and optimism in life $(\mathrm{r}=0.291 ; \mathrm{p}=0.004)$. These relationships are positive, with the first one being moderately strong, and the second one weak. Which means that the poorer the mental well-being, the lower the sense of self-efficacy and optimism in life.

Physical well-being correlated at a statistically significant level with Helplessness $(r=-0.405$; $\mathrm{p}<0.001)$, Avoidance $(\mathrm{r}=-0.222 ; \mathrm{p}=0.30)$, Turning to religion $(\mathrm{r}=-0.315 ; \mathrm{p}=0.002)$, sense of self-efficacy $(\mathrm{r}=0.376 ; \mathrm{p}<0.001)$, and optimism in life $(\mathrm{r}=0.346 ; \mathrm{p}=0.001)$. Relationships with Helplessness, Avoidance, and Turning to religion are negative, which means that the higher the score for these strategies, the lower the level of respondents' 
physical well-being. On the other hand, relationships with the sense of self-efficacy and optimism are positive.

In the final part of the study, we performed a linear regression analysis with the stepwise method. Mental well-being was the dependent variable in the model. The quantitative variables which significantly correlated with this variable were used as predictors. The results of analysis showed that self-efficacy was the strongest predictor, explaining the highest percentage of variance. The $R^{2}$ value indicates that about $16.1 \%$ of the variability in mental well-being can be explained by the self-efficacy. Furthermore, adding the Avoidance behaviour to predictors' pool to the model will cause a statistically significant increase in the model efficiency. These two predictors explain $17.9 \%$ of the variability of mental well-being. The results are provided in Table III.

Tab. III. This is the Table III. Summary of prediction properties of two models for the dependent variable of mental and physical well-being levels.

The results of analysis showed that Helplessness scale was the strongest predictor, explaining the highest percentage of variance in physical well-being (Table III) allowing to predict $16 \%$ of the physical well-being variance. However, adding second parameter to the model: the sense of self-efficacy causes a $21 \%$ increase to overall variance. The unstandardised B coefficient indicates that increase of Helplessness score by one unit resulting in 0.45 unit decrease in physical well-being score. On the other hand, increase in self-efficacy score by one unit causes a 0.06 unit decrease in physical well-being score. 


\section{Discussion}

The authors believe that due to the restrictive and controlling nature of sociotherapy, employees working at sociotherapy centres need to be competent and have a particular skillset to work with their residents. The psychosocial work conditions of teachers and educators, their health state, and ability to cope with occupational stress have not been the subject of scientific research so far.

The detailed analysis of physical health scores showed that the respondents frequently assessed their health as bad or quite bad, had more headaches, experienced tightness and/or pain in the chest, and more often felt weak and distracted. S. Seidman and J. Zager [17] have already shown that among teachers' physical ailment symptoms may reflect difficulties in coping with occupational stress and may manifest as pain, depressive disorders, and a tendency to suffer from colds. Somatic symptoms, such as chronic fatigue, migraine headaches, insomnia, and gastric disorders are also typical signs of emotional exhaustion, which may lead to professional burnout $[18,19]$.

The authors believe data on sleep patterns of the respondents should be investigated further. The results of this study are consistent with the data on this professional group available in the literature. The study conducted by C. Reece-Peters among German teachers showed that nearly $30 \%$ of the subjects experienced sleep problems [20]. J. C. de Souza et al. [21] showed that secondary school teachers presented symptoms of partial sleep deprivation and poor quality of sleep. This may contribute to excessive sleepiness during the day, affect employees' health, quality of life, and teaching abilities. Sleep disorders are a very common complication of depression and may be associated with an increased risk of significant depression and suicidal tendencies [22] Whereas, sleep disorders caused by chronic stress can contribute to the risk of occupational burnout. At the same time, it was found that increased physical 
activity and proper sleep hygiene ensure high quality of sleep and may buffer the adverse effects of occupational stress [23-25].

In this study, the sense of self-efficacy proved to be the strongest predictor of mental wellbeing. The authors proved that the sense of self-efficacy is a measure of predicting educational efficacy and ability to solve pedagogical problems [26,27]. The higher the sense of self-efficacy, the higher the objectives people set for themselves and the stronger is their commitment [28]. Teachers with a high sense of self-efficacy are more motivated and efficient in their work. A positive image of oneself as an employee, measured through own actions and efficacy, helps to foster a positive perception of one's mental health [29].

In this study, sex was a diversifying factor for the study group in terms of the mental and physical well-being. Published literature generally supports the idea that indicators for mental disorders are significantly higher in women than men $(33.2 \%$ versus $21.7 \%)$, also when a professional activity variable is considered (55.4\% versus $4.6 \%)$ [30,31]. Higher depression and anxiety indicators in the group of women are associated with work factors, such as high requirements and low decision-making power [32]. Studies show that women are particularly exposed to occupational stress factors including multiple roles conflict, discrimination, stereotypes, and a lack of career development [33].

Interestingly, it turned out that work experience, which is another socio-demographic variable, did not influence the mental and physical well-being of examined employees. As other analyses have shown, it can be a significant, positive predictor of job satisfaction in a group of teachers $[34,35]$. People working in helping professions are exposed to stress factors which may affect their mental and physical well-being. Due to the particular nature of sociotherapy and the work environment in sociotherapy centres, teachers and educators are required to adapt and act in a specific way to be effective. Therefore, in this study we attempted to evaluate the influence of strategies for coping with occupational load on 
subjects' mental and physical well-being. The strategies of Helplessness, Avoidance behaviours, and Turning to religion correlated with mental well-being. These strategies contrast with proactive approach and actively working towards making a positive change. Studies conducted on other helping professions, such as hospital nurses and social workers, indicate that exhibiting passive behaviours in response to stress and lack of support may contribute to emotional exhaustion at work, being a symptom of professional burnout $[36,37]$.

The correlation analyses showed that mental and physical well-being at work is linked to the level of optimism in life. This is confirmed by studies in secondary school teachers, which show a negative relationship between the optimism in life and causes of occupational burnout, such as personal commitment and emotional exhaustion [38]. Pessimists are more prone to experience physical exhaustion and a lower sense of professional accomplishments.

In this study, $30-40 \%$ of the employees suffered from frequent or continual states of irritation, depression, stress, and nervousness. People who have problems coping with occupational stress are more prone to experience the above-mentioned conditions, pain and colds [39]. On the other hand, the ability to recognise, express, and control one's emotions (i.e., emotional intelligence) influences the ability to cope with stress in helping professions. Also, it may affect the relationship between perceived stress and consequences resulting from certain associated experiences $[40,41]$.

The presented study has its limitations. Workplace stressors were not included in the presented results. For example, we did not analyse the following issues which can play a significant role in regulating stress: dealing with discipline in the classroom, conflicting expectations of teachers and students, and performing tasks under time pressure. The authors of the study did not control any non-work factors, such as other stressful events in a subject's personal life, that could have potentially influenced teachers' mental well-being. 
347 According to Ch. Kyriacou [42], studies conducted on a group of teachers should focus on the

348 effectiveness of interventional strategies intended to reduce stress level. Occupational burnout

349 and its influence on teachers' mental and physical well-being are other aspects that should be

350 studied more thoroughly. The available data indicate that this adverse phenomenon may

351 explain the relation between high expectations at work and poor health of people working in

352 helping professions [43].

\section{Conclusions}

1. People working in helping professions and employed at youth educational centres and sociotherapy centres have difficulty sleeping. Sleep disorders caused by chronic stress may be associated with an increased risk of depression.

2. It was found that women reported significantly worse mental and physical well-being at work than men.

3. People with poorer mental and physical well-being are more likely to cope with stress by giving into Helplessness, Avoidance behaviours or Turning to religion. 


\section{References}

1. Assessment of Potentially Stressful Work and Organisational Environments: Theory and Method In: Wilson JR, Sharples S, editors. Evaluation of Human Work. London: CRS Press; 4th ed. 2015. p.565-582.

2. Sauter SL, Murphy LR. Organizational risk factors for job stress. Washington DC: American Psychological Association; 1995.

3. Widerszal-Bazyl M, Cieślak M. Monitoring psychosocial stress at work: development of the Psychosocial Working Conditions Questionnaire._Int J Occup Saf Ergon. 2000;6:59-70.

4. Briner RB, Poppleton S, Owens S, Kiefer T. The nature, causes and consequences of harm in emotionally-demanding occupations. London; Birkbeck College University of London for the Health and Safety Executive; 2008.

5. Kirkcaldy B, Shephard RJ. Occupational stress, work satisfaction and health among the helping professions. Eur Rev Appl Psychol. 2001;51(4):243-253.

6. Kyriacou Ch, Sutcliffe J. Teacher Stress: a review. Educ Rev. 1977;29:299-306.

7. Bowers T. Stress, teaching and teacher health. Education. 2004;32(3):73-80.

8. Ratliff N. Stress and Burnout in the Helping Professions. Soc Casework. 1988;69: $147-54$.

9. Scott Huebner E. Professionals under stress: A review of burnout among the helping professions with implications for school psychologists. Psychology in the Schools. 1993;30:40-49.

10. Louise G, Gail K. Emotional Resilience in the Helping Professions and how it can be Enhanced. Health and Social Care Education. 2015;3(1):23-34. 
11. Chow EO, Ho HC. The relationship between psychological resources, social resources, and depression: results from older spousal caregivers in Hong Kong. Aging Ment health. 2012;16(8):1016-27.

12. Antoniou AS, Ploumpi A, Ntalla M. Occupational Stress and Professional Burnout in Teachers of Primary and Secondary Education: The Role of Coping Strategies. Psych. 2013;4(3):349-355.

13. Sheridan CL, Radmacher SA. Health psychology: challenging the biomedical model. 2nd ed. New Jersey: Wiley; 1992.

14. Nasser F. Teacher Stress and Coping: The Role of Personal and Job Characteristics. Procedia - Social and Behavioral Sciences. 2015;185:374-380.

15. Cieślak R, Widerszal - Bazyl M. Psychospołeczne warunki pracy. Podręcznik do kwestionariusza. Warszawa: Centralny Instytut Ochrony Pracy; 2000.

16. Juczyński Z, Ogińska-Bulik N. Narzędzia Pomiaru w Psychologii Zdrowia. Warszawa: Pracownia Testów Psychologicznych Polskiego Towarzystwa Psychologicznego; 2009.

17. Seidman SA, Zager J. A study of coping behaviors and teacher burnout. Work Stress. 1991;5:205-216.

18. Glise K, Ahlborg G, Jonsdottir IH. Prevalence and course of somatic symptoms in patients with stress-related exhaustion: does sex or age matter. BMC Psychiatry. 2014;14:118.

19. Koehler U, Koehler YL. ["Burnout"—Krankheit oder Folge von Stress?]. Dtsch Med Wochenschr. 2014;139(34-35):1731-4.

20. Reece-Peters C. Teachers' issues: A case for mental health. Augustine, Trinidad and Tobago: The University of the West Indies Schools of Education. 2013. Available from: http http://uwispace.sta.uwi.edu/dspace/handle/2139/15697. 
21. de Souza JC, de Sousa IC, Belísio AS, Macêdo de Azevedo CV. Sleep habits, daytime sleepiness and sleep quality of high school teachers. Psychol Neurosci. 2012;5(2): 257-263. http://dx.doi.org/10.3922/j.psns.2012.2.17.

22. Nutt D, Wilson S, Paterson L. Sleep disordes as a core symptoms of depression. Dialogues Clin Neurosci. 2008; 10(3):329-336.

23. Kottwitz MU, Gerhardt C, Pereira D, Iseli L, Elfering A. Teacher's sleep quality: linked to social job characteristics? Ind Health. 2018;56(1):53-61.

24. Flueckiger L, Lieb R, Meyer AH., Witthauer C, Mata J. The importance of physical activity and sleep for affect on stressful days: Two intensive longitudinal studies. Emotion. 2016;16(4):488-497.

25. Nishinoue N, Takano T, Kaku A, Eto R, Kato N, Ono Y. Sleep Hygiene Education and Behavioral Therapy on Sleep Quality of White-collar Workers: A Randomized Controlled Trial. Ind Health. 2012;50:123-131.

26. Korur EN. The Relationship between preservice physical education teacher's academic self-efficacy and proactive personality. International Journal of Anatolia Sport Sciences. 2018;3.281-293.

27. Woolfolk AE, Hoy WK. Prospective teachers' sense of efficacy and beliefs about control. Journal of Educational Psychology.1990;82,81-91.

28. Woolfolk Hoy A, Davis HA. Teachers' self-efficacy and its influence on the achievement of adolescents. In: Pajares F, Urdan T, editors. Self-efficacy beliefs of adolescents Greenwich, CT: Information Age Publishing; 2006. p. 117-137.

29. Schwarzer R, Hallum S. Perceived teacher self-efficacy as a predictor of job stress and burnout: Mediation analyses. Applied Psychology: An International Review. Special Issue: Health and Well-Being. 2008;57:152-171. 
30. Burke RJ. Work experiences, stress and health among managerial women: Research and practice. In: Schabracq MJ, Winburst JAM, Cooper CL, editors. The Handbook of Work and Health Psychology. Wiltshire: John Wiley \& Sons, 2003. p. $259-278$.

31. Astbury J, Cabral M. Women's Mental Health: An Evidence Based Review, Geneva: World Health Organization. 2000. Available from: http://apps.who.int/iris/bitstream/handle/10665/66539/WHO_MSD_MDP_00.1.pd f?sequence $=1$

32. Williams RB, Barefoot JC, Blumenthal JA, Helms MJ, Luecken L, Pieper CF. Psychosocial correlates of job strain in a sample of working women. Arch Gen Psychiatry. 1997;54(6):543-8.

33. Lennon MC. Work conditions as explanations for the relation between socioeconomic status, gender, and psychological disorders. Epidemiol Rev. $1995 ; 17: 120-7$.

34. Gesinde A, Adejumo, G. Effects of Age and Work Experience on Job Satisfaction of Primary School Teachers: Implications for Career Counseling. International Journal of Asian Social Science. 2012; 2(3):302-9.

35. Akhtar SN, Hashmib MA, Naqvic SIH. A comparative study of job satisfaction in public and private school teachers at secondary level. Procedia Soc Behav Sci $2010 ; 2: 4222-8$.

36. Lambert VA, Lambert CE, Ito M. Workplace stressors, ways of coping and demographic characteristics as predictors of physical and mental health of Japanese hospital nurses. Int J of Nurs Stud. 2004;41(1):85-97. 
38. Terelak JF, Mystkowski M. Optymizm a wypalenie zawodowe u nauczycieli. Studia Psychologica UKSW. 2010;(10):153-178.

39. Seidman SA, Zager J. A study of coping behaviors and teacher burnout. Work \& Stress. 1991;5:205-216.

40. Morrison T. Emotional Intelligence, emotion and social work: context, characteristics, complications and contribution. Br J Soc Work. 2007;37(2):245263.

41. Duran A, Extremera N. Self-reported emotional intelligence, burnout and engagement among staff in services for people with intellectual disabilities. Psychol Rep 2004; 95(2):386-92.

42. Kyriacou C. Teacher Stress: Directions for future research. Educational Review. 2001;53(1):27-35.

43. Hakanen JJ, Bakker AB., Schaufeli WB. Burnout and work engagement among teachers. Journal Sch Psychol. 2006;43(6):495-513. 
Table. I. Qualitative analyses of subjects' responses versus standards for teachers (D2 scale; mental well-being)

\begin{tabular}{|c|c|c|c|c|c|c|c|c|c|c|c|}
\hline Responses & $\begin{array}{l}\text { How satisfied } \\
\text { are you with } \\
\text { your current } \\
\text { job? } \\
\text { Percentage of } \\
\text { subjects' } \\
\text { responses/ } \\
\text { standards for } \\
\text { teachers }\end{array}$ & $\begin{array}{l}\text { How satisfied } \\
\text { are you with } \\
\text { your life at } \\
\text { present? }\end{array}$ & $\begin{array}{l}\text { Are you feeling } \\
\text { more tired than } \\
\text { usual recently? } \\
\text { Percentage of } \\
\text { subjects' } \\
\text { responses } \\
\text { /standards for } \\
\text { teachers }\end{array}$ & $\begin{array}{l}\begin{array}{l}\text { Do other } \\
\text { people } \\
\text { annoy you? }\end{array} \\
\text { Percentage } \\
\text { of subjects' } \\
\text { responses } \\
\text { /standards } \\
\text { for teachers }\end{array}$ & $\begin{array}{l}\begin{array}{l}\text { Do you feel } \\
\text { depressed? }\end{array} \\
\text { Percentage of } \\
\text { subjects' } \\
\text { responses } \\
\text { /standards for } \\
\text { teachers }\end{array}$ & $\begin{array}{l}\text { Are you } \\
\text { nervous? } \\
\\
\text { Percentage of } \\
\text { subjects' } \\
\text { responses } \\
\text { /standards for } \\
\text { teachers }\end{array}$ & $\begin{array}{l}\begin{array}{l}\text { Do you feel } \\
\text { lonely? }\end{array} \\
\\
\text { Percentage } \\
\text { of subjects' } \\
\text { responses } \\
\text { /standards } \\
\text { for teachers }\end{array}$ & $\begin{array}{l}\text { Do you have } \\
\text { problems } \\
\text { collecting your } \\
\text { thoughts or } \\
\text { concentrating? } \\
\text { Percentage of } \\
\text { subjects' } \\
\text { responses } \\
\text { /standards for } \\
\text { teachers }\end{array}$ & $\begin{array}{l}\begin{array}{l}\text { Do you feel } \\
\text { well rested } \\
\text { and full of } \\
\text { energy? }\end{array} \\
\text { Percentage } \\
\text { of subjects' } \\
\text { responses } \\
\text { /standards } \\
\text { for teachers }\end{array}$ & $\begin{array}{l}\text { Do you feel } \\
\text { self- } \\
\text { confident? }\end{array}$ & $\begin{array}{l}\begin{array}{l}\text { Do you } \\
\text { think that } \\
\text { you do your } \\
\text { work well? }\end{array} \\
\text { Percentage } \\
\text { of subjects' } \\
\text { responses } \\
\text { /standards } \\
\text { for teachers }\end{array}$ \\
\hline Never & $\begin{array}{l}4.17 \% \\
/ 18.8 \%\end{array}$ & $\begin{array}{c}\mathbf{0 \%} \\
/ 19.8 \%\end{array}$ & $\begin{array}{c}9.38 \% \\
/ 5.8 \%\end{array}$ & $\begin{array}{c}2.88 \% \\
15 \%\end{array}$ & $\begin{array}{l}4.8 \% \\
/ 2.5 \%\end{array}$ & $\begin{array}{c}\mathbf{6 . 7 2 \%} \\
/ 0.6 \%\end{array}$ & $\begin{array}{l}4.17 \% \\
/ 27.9 \%\end{array}$ & $\begin{array}{c}3.84 \% \\
/ 6.9 \%\end{array}$ & $\begin{array}{l}3.13 \% \\
/ 10.4 \%\end{array}$ & $\begin{array}{l}\mathbf{3 0} \% \\
/ 4.8 \%\end{array}$ & $\begin{array}{c}\mathbf{2 5 . 0 4 \%} \\
/ 20.6 \%\end{array}$ \\
\hline $\begin{array}{l}\text { Rather } \\
\text { rarely }\end{array}$ & $\begin{array}{l}\mathbf{9 . 3 8 \%} \\
/ 56.8 \%\end{array}$ & $\begin{array}{l}\mathbf{5 . 2 1 \%} \\
/ 55.9 \%\end{array}$ & $\begin{array}{c}\mathbf{1 6 . 6 7 \%} \\
/ 25.5 \%\end{array}$ & $\begin{array}{l}\mathbf{8 . 6 4 \%} \\
/ 32.3 \%\end{array}$ & $\begin{array}{l}\mathbf{8 . 6 4 \%} \\
/ 41.7 \%\end{array}$ & $\begin{array}{c}\mathbf{1 0 . 5 6 \%} \\
/ 34 \%\end{array}$ & $\begin{array}{l}\mathbf{3 . 1 3 \%} \\
/ 41.3 \%\end{array}$ & $\begin{array}{c}6.72 \% \\
156 \%\end{array}$ & $\begin{array}{l}9.38 \% \\
/ 51.5 \%\end{array}$ & $\begin{array}{l}\mathbf{8 . 3 3 \%} \\
/ 55.8 \%\end{array}$ & $\begin{array}{l}3.13 \% \\
/ 67.9 \%\end{array}$ \\
\hline $\begin{array}{l}\text { From time } \\
\text { to time }\end{array}$ & $\begin{array}{c}\mathbf{2 0 . 8 3} \% \\
/ 20 \%\end{array}$ & $\begin{array}{c}\mathbf{1 4 . 5 8 \%} \\
/ 16.5 \%\end{array}$ & $\begin{array}{l}\mathbf{6 . 8 8 \%} \\
/ 41.8 \%\end{array}$ & $\begin{array}{c}\mathbf{4 5 . 1 2 \%} \% \\
/ 59.2 \%\end{array}$ & $\begin{array}{c}37.44 \% \\
/ 46.5 \%\end{array}$ & $\begin{array}{c}42.24 \% \\
/ 44 \%\end{array}$ & $\begin{array}{c}\mathbf{2 9 . 1 7 \%} \% \\
/ 21.9 \%\end{array}$ & $\begin{array}{l}\mathbf{3 5 . 5 \%} \\
/ 32.3 \%\end{array}$ & $\begin{array}{c}\mathbf{3 4 . 3 8 \%} \\
/ 29.4 \%\end{array}$ & $\begin{array}{c}\mathbf{2 6 . 0 4 \%} \% \\
/ 29.6 \%\end{array}$ & $\begin{array}{c}\mathbf{1 1 . 4 6 \%} \\
/ 11 \%\end{array}$ \\
\hline $\begin{array}{c}\text { Rather } \\
\text { frequently }\end{array}$ & $\begin{array}{c}\mathbf{5 4 . 1 7 \%} \\
/ 3.3 \%\end{array}$ & $\begin{array}{c}\mathbf{5 3 . 1 3 \%} \\
/ 6.3 \%\end{array}$ & $\begin{array}{c}\mathbf{1 5 . 6 3 \%} \\
/ 23 \%\end{array}$ & $\begin{array}{c}31.68 \% \\
/ 5.6 \%\end{array}$ & $\begin{array}{c}\mathbf{3 3 . 5 9 \%} \\
/ 7.9 \%\end{array}$ & $\begin{array}{c}\mathbf{2 6 . 8 8 \%} \\
/ 18.3 \%\end{array}$ & $\begin{array}{c}\mathbf{3 9 . 5 8 \%} \\
/ 6.5 \%\end{array}$ & $\begin{array}{c}3.84 \% \\
/ 4 \%\end{array}$ & $\begin{array}{c}\mathbf{4 0 . 6 3 \%} \% \\
/ 6.9 \%\end{array}$ & $\begin{array}{l}\mathbf{5 0 \%} \\
/ 9.2 \%\end{array}$ & $\begin{array}{c}\mathbf{6 0 . 4 \%} \\
/ 0.2 \%\end{array}$ \\
\hline Continually & $\begin{array}{c}11.46 \% \\
/ 1 \%\end{array}$ & $\begin{array}{c}\mathbf{2 7 . 0 8 \%} \\
/ 1.5 \%\end{array}$ & $\begin{array}{c}11.46 \% \\
/ 4 \%\end{array}$ & $\begin{array}{c}3.84 \% \\
/ 1.5 \%\end{array}$ & $\begin{array}{l}7.68 \% \\
/ 1.5 \%\end{array}$ & $\begin{array}{c}\mathbf{5 . 7 6 \%} \\
/ 3.1 \%\end{array}$ & $\begin{array}{c}\mathbf{2 3 . 9 8 \%} \\
/ 2.5 \%\end{array}$ & $\begin{array}{c}7.68 \% \\
/ 0.8 \%\end{array}$ & $\begin{array}{c}\mathbf{1 2 . 5 0} \% \\
/ 1.9 \%\end{array}$ & $\begin{array}{c}\mathbf{1 5 . 6 3 \%} \\
/ 1.3 \%\end{array}$ & $\begin{array}{c}\mathbf{0 \%} \\
/ 0.2 \%\end{array}$ \\
\hline
\end{tabular}


Table. II. Qualitative analyses of subjects' responses versus standards for teachers (D1 scale; physical well-being)

\begin{tabular}{|c|c|c|c|c|c|c|c|c|c|c|c|}
\hline Responses & $\begin{array}{l}\text { How often } \\
\text { do you feel } \\
\text { stressed? } \\
\text { (condensed } \\
\text { question) } \\
\\
\text { Percentage } \\
\text { of subjects' } \\
\text { responses/ } \\
\text { standards } \\
\text { for teachers }\end{array}$ & $\begin{array}{l}\text { How would } \\
\text { you describe } \\
\text { your health } \\
\text { as compared } \\
\text { to other } \\
\text { people at your } \\
\text { age? } \\
\text { Percentage of } \\
\text { subjects' } \\
\text { responses } \\
\text { /standards for } \\
\text { teachers } \\
\end{array}$ & $\begin{array}{l}\text { Do you have } \\
\text { headaches? } \\
\\
\text { Percentage of } \\
\text { subjects' } \\
\text { responses } \\
\text { /standards for } \\
\text { teachers }\end{array}$ & $\begin{array}{l}\begin{array}{l}\text { Do you } \\
\text { often have } \\
\text { increased } \\
\text { heart rate? }\end{array} \\
\\
\text { Percentage } \\
\text { of subjects' } \\
\text { responses } \\
\text { /standards } \\
\text { for teachers }\end{array}$ & $\begin{array}{l}\begin{array}{l}\text { Do you } \\
\text { experience } \\
\text { palpitation? }\end{array} \\
\\
\text { Percentage of } \\
\text { subjects' } \\
\text { responses } \\
\text { /standards for } \\
\text { teachers } \\
\end{array}$ & $\begin{array}{l}\text { Percentage of } \\
\text { subjects' } \\
\text { responses } \\
\text { /standards for } \\
\text { teachers }\end{array}$ & $\begin{array}{l}\text { Percentage } \\
\text { of subjects' } \\
\text { responses } \\
\text { /standards } \\
\text { for teachers } \\
\end{array}$ & $\begin{array}{l}\begin{array}{l}\text { Do you } \\
\text { experience } \\
\text { chest tightness } \\
\text { and/or pain? }\end{array} \\
\\
\text { Percentage of } \\
\text { subjects' } \\
\text { responses } \\
\text { /standards for } \\
\text { teachers }\end{array}$ & $\begin{array}{l}\begin{array}{l}\text { Do you } \\
\text { have } \\
\text { stomach } \\
\text { problems? }\end{array} \\
\\
\text { Percentage } \\
\text { of subjects' } \\
\text { responses } \\
\text { /standards } \\
\text { for teachers }\end{array}$ & $\begin{array}{l}\text { Percentage of } \\
\text { subjects' } \\
\text { responses } \\
\text { /standards for } \\
\text { teachers }\end{array}$ & $\begin{array}{l}\text { Percentage } \\
\text { of subjects' } \\
\text { responses } \\
\text { /standards } \\
\text { for teachers } \\
\end{array}$ \\
\hline Never & $\begin{array}{l}6.25 \% \\
/ 1.9 \%\end{array}$ & $\begin{array}{l}\mathbf{1 4 . 5 8 \%} \\
/ 12.1 \% \\
\text { (very good } \\
\text { health) }\end{array}$ & $\begin{array}{l}22.91 \% \\
/ 21.3 \%\end{array}$ & $\begin{array}{c}13.54 \% \\
/ 18 \%\end{array}$ & $\begin{array}{l}\mathbf{2 8 . 1 3 \%} \\
/ 35.9 \%\end{array}$ & $\begin{array}{c}\mathbf{1 6 . 6 7 \%} \\
/ 11.5 \%\end{array}$ & $\begin{array}{c}\mathbf{4 3 . 7 5 \%} \\
/ 41.5 \%\end{array}$ & $\begin{array}{c}\mathbf{2 8 . 1 2 \%} \\
/ 39 \%\end{array}$ & $\begin{array}{c}\mathbf{2 6 . 0 4 \%} \\
/ 34.6 \%\end{array}$ & $\begin{array}{c}\mathbf{2 7 . 0 8 \%} \\
/ 26.5 \% \\
\text { (very easily) }\end{array}$ & $\begin{array}{l}\mathbf{2 . 8 8 \%} \\
/ 47.5 \% \\
\text { (usually I do } \\
\text { not wake up } \\
\text { at night) } \\
\end{array}$ \\
\hline $\begin{array}{l}\text { Rather } \\
\text { rarely }\end{array}$ & $\begin{array}{l}\mathbf{3 7 . 5 \%} \\
/ 20.6 \%\end{array}$ & $\begin{array}{l}\mathbf{1 3 . 5 4 \%} \\
/ 41.5 \% \\
\text { (rather good } \\
\text { health) }\end{array}$ & $\begin{array}{c}\mathbf{2 9 . 1 6 \%} \\
/ 32.1 \%\end{array}$ & $\begin{array}{c}\mathbf{3 8 . 5 4 \%} \\
/ 39.7 \%\end{array}$ & $\begin{array}{l}28.13 \% \\
/ 30.5 \%\end{array}$ & $\begin{array}{c}\mathbf{1 9 . 8 0 \%} \\
/ 35.6 \%\end{array}$ & $\begin{array}{c}35.42 \% \\
/ 44.8 \%\end{array}$ & $\begin{array}{c}35.42 \% \\
/ 35 \%\end{array}$ & $\begin{array}{l}42.7 \% \\
/ 32.5 \%\end{array}$ & $\begin{array}{c}\mathbf{4 2 . 7 \%} \\
/ 37.3 \% \\
\text { (rather easily) }\end{array}$ & $\begin{array}{c}\mathbf{0 \%} \\
130 \% \\
\text { (wake up } \\
\text { once a night) }\end{array}$ \\
\hline $\begin{array}{l}\text { From time } \\
\text { to time }\end{array}$ & $\begin{array}{l}\mathbf{3 3 . 3} \% \\
/ 43.5 \%\end{array}$ & $\begin{array}{c}\mathbf{3 3 . 3 3 \%} \\
/ 39.6 \% \\
\text { (average } \\
\text { health) }\end{array}$ & $\begin{array}{l}31.25 \% \\
/ 34.2 \%\end{array}$ & $\begin{array}{l}\mathbf{2 8 . 1 3 \%} \\
/ 33.1 \%\end{array}$ & $\begin{array}{l}\mathbf{2 9 . 1 7 \%} \\
/ 27.3 \%\end{array}$ & $\begin{array}{c}\mathbf{2 9 . 1 7 \%} \\
/ 41 \%\end{array}$ & $\begin{array}{c}\mathbf{1 5 . 6 3 \%} \\
/ 10.6 \%\end{array}$ & $\begin{array}{l}\mathbf{2 0 . 8 3 \%} \\
/ 21.5 \%\end{array}$ & $\begin{array}{l}21.87 \% \\
/ 22.1 \%\end{array}$ & $\begin{array}{c}\mathbf{1 5 . 6 2 \%} \\
/ 22.7 \% \\
\text { (neither easily } \\
\text { nor with } \\
\text { difficulty) } \\
\end{array}$ & $\begin{array}{c}\mathbf{1 8 . 2 4 \%} \\
/ 17.5 \% \\
\text { (wake up 2- } \\
3 \text { times) } \\
\end{array}$ \\
\hline $\begin{array}{c}\text { Rather } \\
\text { frequently }\end{array}$ & $\begin{array}{l}\mathbf{1 1 . 4 5 \%} \\
/ 24.6 \%\end{array}$ & $\begin{array}{c}\mathbf{2 0 . 8 3 \%} \\
/ 6.3 \% \\
\text { (rather poor) }\end{array}$ & $\begin{array}{l}9.37 \% \\
/ 11.7 \%\end{array}$ & $\begin{array}{c}\mathbf{1 0 . 4 1 \%} \\
/ 7.3 \%\end{array}$ & $\begin{array}{l}8.38 \% \\
/ 3.8 \%\end{array}$ & $\begin{array}{c}\mathbf{1 7 . 7 \%} \\
/ 8.3 \%\end{array}$ & $\begin{array}{l}\mathbf{2 . 0 8 \%} \\
/ 1.9 \%\end{array}$ & $\begin{array}{c}6.25 \% \\
/ 3.5 \%\end{array}$ & $\begin{array}{c}4.16 \% \\
/ 7.7 \%\end{array}$ & $\begin{array}{c}\mathbf{8 . 3 3 \%} \\
/ 10.8 \% \text { (with } \\
\text { quite difficulty) }\end{array}$ & $\begin{array}{l}\mathbf{2 3 . 0 4 \%} \\
13.5 \% \\
\text { (wake up 4- } \\
5 \text { times) } \\
\end{array}$ \\
\hline $\begin{array}{l}\text { Continually } \\
\text { (very often) }\end{array}$ & $\begin{array}{c}11.45 \% \\
/ 9.4 \%\end{array}$ & $\begin{array}{c}\mathbf{1 7 . 7 0} \% \\
/ 0.6 \% \\
\text { (very poor) }\end{array}$ & $\begin{array}{c}7.30 \% \\
/ 0.8 \%\end{array}$ & $\begin{array}{l}4.16 \% \\
/ 1.9 \%\end{array}$ & $\begin{array}{l}6.25 \% \\
/ 2.5 \%\end{array}$ & $\begin{array}{c}\mathbf{1 6 . 6 7 \%} \\
/ 3.5 \%\end{array}$ & $\begin{array}{l}\mathbf{3 . 1 3 \%} \\
/ 1.3 \%\end{array}$ & $\begin{array}{c}\mathbf{9 . 3 8 \%} \\
/ 1 \%\end{array}$ & $\begin{array}{l}5.2 \% \\
/ 3.1 \%\end{array}$ & $\begin{array}{l}\mathbf{6 . 2 5 \%} \\
/ 2.7 \% \\
\text { (with big } \\
\text { difficulty) }\end{array}$ & $\begin{array}{l}\mathbf{4 7 . 0 4 \%} \\
/ 1.5 \% \\
\text { (no sleep at } \\
\quad \text { all) }\end{array}$ \\
\hline
\end{tabular}


bioRxiv preprint doi: https://doi org/10.1101/361311: this version posted July 3,2018 . The copyright holder for this preprint (which was not certified by peer review) is the author/funder, who has granted bioRxiv a license to display the preprint in perpetuity. It is made available under aCC-BY 4.0 International license.

Table. III. Summary of prediction properties of two models for the dependent variable of mental and physical well-being levels

\begin{tabular}{|c|c|c|c|c|c|c|}
\hline \multicolumn{7}{|l|}{ Mental well-being } \\
\hline & B & SE & Beta & $\mathrm{R}^{2}$ & $\Delta \mathrm{R}^{2}$ & F change \\
\hline Model 1 & & & & 0.16 & & $18.02 * *$ \\
\hline (Constant) & 1.24 & 0.55 & & & & \\
\hline Sense of self-efficacy & 0.08 & 0.02 & $0.40 * *$ & & & \\
\hline Model 2 & & & & 0.18 & 0.04 & $11.37 * *$ \\
\hline (Constant) & 1.76 & 0.60 & & & & \\
\hline Sense of self-efficacy & 0.07 & 0.02 & $0.37 * *$ & & & \\
\hline Avoidance & -0.24 & 0.12 & $-0.19 *$ & & & \\
\hline \multicolumn{7}{|l|}{ Physical well-being } \\
\hline Model 1 & & & & & 0.16 & $18.41 * * *$ \\
\hline (Constant) & 4.19 & 0.13 & & & & \\
\hline Helplessness & -0.58 & 0.14 & $-0.41 * * *$ & & & \\
\hline Model 2 & & & & 0.21 & 0.06 & $7.36 * *$ \\
\hline (Constant) & 2.33 & 0.7 & & & & \\
\hline Helplessness & -0.45 & 0.14 & $-0.31 * *$ & & & \\
\hline Sense of self-efficacy & 0.06 & 0.02 & $0.27 * *$ & & & \\
\hline
\end{tabular}

